HOLISTIK NURSING AND HEALTH SIENCE 1, (1), 2018 35-45

Available Online at https://ejournal2.undip.ac.id/index.php/hnhs

\title{
Effects of Mindfulness with Gayatri Mantra on Decreasing Anxiety in the Elderly
}

\author{
Sang Ayu Ketut Candrawati ${ }^{1}$, Meidiana Dwidiyanti ${ }^{2}$, Rita Hadi Widyastuti ${ }^{3}$ \\ ${ }^{1}$ Student of Master Program in Nursing, Diponegoro University, Semarang, Indonesia \\ ${ }^{2,3}$ Departement of Nursing, Diponegoro University, Semarang, Indonesia \\ Corresponding Author: Meidiana Dwidiyanti (meidiana@fk.undip.ac.id)
}

\begin{abstract}
Background: Anxiety is one of the psychological problems which can develop in the elderly. If left untreated, it can decrease the productivity and quality of life. Mindfulness with Gayatri mantra is such a complementary therapy which is effective to reduce anxiety in the elderly.

Objective: The purpose of this study was to determine the effects of mindfulness with Gayatri mantra on decreasing anxiety in the elderly Hindus in Bali, Indonesia.

Methods: This study employed a one group pre and posttest quasi-experimental design and involved 34 elderly people recruited using a purposive sampling technique. Anxiety was measured using the Geriatric Anxiety Scale (GAS). A t-test statistical analysis was used to analyze the data.

Results: Results showed that there were significant effects of mindfulness with Gayatri mantra on decreasing the anxiety in the elderly Hindus in Bali with a p-value of 0.000 $(\alpha$-value $=0.05)$.

Conclusion: Mindfulness with Gayatri mantra could decrease anxiety in the elderly Hindus. This therapy can be used as an alternative to prevent the recurrence of anxiety in the elderly.
\end{abstract}

Keywords: Anxiety and the elderly; mindfulness; Gayatri mantra

\section{INTRODUCTION}

The increased life expectancy can affect the rate of growth of the elderly (MHRI, 2014). In Indonesia, the proportion of the elderly in 2012, 2013 and 2014 were $7.59 \%, 8.9 \%$, and $9.12 \%$ of the total population, respectively. It is predicted that this number will reach $21.4 \%$ by 2050 . There are four provinces in Indonesia with the largest elderly population, i.e., Yogyakarta (13.05\%), Central Java (11.11\%), East Java (10.96\%) and Bali (10.05\%) (MHRI, 2014; Central Bureau of Statistics, 2015). The increasing number of elderly population in Indonesia has led the country to be one of the nations with an aging population (MHRI, 2014).

The elderly are susceptible individuals in the final stage of aging cycle as characterized by decreased organ functions and immunity which affect the life (Mujahidullah, 2012). Such changes occur naturally and cause the elderly to be more vulnerable to physical illness and psychosocial problems (Mujahidullah, 2012; Nursalam, 2015). The impacts of aging on the elderly health may include the physical, psychological (anxiety, stress, and depression) and socio-economic effects (MHRI, 2014; Nursalam, 2015). Anxiety is 
HOLISTIK NURSING AND HEALTH SIENCE 1, (1), 2018 35-45

a psychological change which mostly occurs in the elderly (Yusuf, Fitryasari \& Nihayati, 2015).

The prevalence of anxiety in the adulthood and the elderly in developing countries reaches to $50 \%$ with the incidence ranging from $3.2 \%$ to $14.2 \%$ (Taylor, Castriotta, Lenze, Stanley, \& Craske, 201). A study by Irshad and Chaudhry (2015) revealed that $15 \%$ out of 500 older adults with the age of 60 and over experienced anxiety. In Indonesia, the incidence of anxiety is 39 million (16.38\%) out of 238 million of total population (Subandi \& Suprianto, 2013). Anxiety occurs more in women (31\%) than men (19\%) with a ratio of 2:1 (Hawari, 2011; Safaria, 2012), indicating that women tend to experience anxiety more frequently than men.

High rates of comorbid anxiety and other psychiatric problems in the elderly make it difficult to identify the source and symptoms of anxiety in the elderly (Mahoney, Segal, $\&$ Coolidge, 2015). More than $90 \%$ of adults aged 50 or older do not report any anxiety diagnosis during their lifetime (Centers for Disease Control and Prevention, 2010). Anxiety is a subjective emotional response as a result of either identifiable or unknown threat with uncertain fear or worries and tensed physical symptoms (Yusuf, Fitryasari, Rizky \& Hanik, 2015; Mahoney, Segal, \& Coolidge, 2015). Anxiety is defined as a threat of self-esteem based on the assumption of unclear objects.

Long-term effects of psychological problems in the elderly can give negative influences on the health, and lead to anxiety symptoms. Neurotic disorders such as acute anxiety or panic disorder can cause dangerous disruption or behaviors. In a difficult situation, almost all patients can act aggressively and pose a risk to the safety of oneself and others (Davies \& Craig, 2014).

Some studies have indicated that meditation is an effective method to overcome or decrease anxiety in the elderly. The most popular form of meditation nowadays is mindfulness. Jon Kabat-Zinn defines mindfulness as mindful meditation, being aware of present conditions-here (now) without any judgment (Didonna, 2008; Tomaselli, 2014). Mindfulness is proven to be effective for decreasing psychological problems, such as anxiety, depression, and insomnia (Abadi, 2012).

Gayatri mantra meditation is a popular meditation among Hindu people (Antariksawan, 2015; Bali-MSC, 2014). Gayatri mantra is a belief manifested in "prayer and mantra." Repetition of mantra is helpful for developing thinking skills and characters, protection, mental cure, fear and emotional control (Baba, 1996; Keshavadas, 2007). Mindfulness with Gayatri mantra is a combination of consciousness and belief that leads individuals to an acceptance of every event occurring at present in their life. Acceptance of the illness is a part of the healing process. This meditation does not conflict with the beliefs or traditions, religion, culture or science (Directorate General of Learning and Student Affairs, 2016). Gayatri mantra gave effects on the changes of EEG in patients after the patients listened to it, indicating that Gayatri mantra meditation influenced the changes in the brain waves (Thomas \& Rao, 2016).

Based on a preliminary study in Tresna Werdha social home in Wana Seraya, Denpasar, in September 2016, it was identified that 48 elderly people in total were living in the 
home, consisting of 35 women and 13 men. Out of this number, 20 were screened for anxiety using the depression anxiety stress scale (DASS). The results indicated that 12 $(60 \%)$ people were identified to experience anxiety, in which 7 (35\%) had mild anxiety, and the other $5(25 \%)$ had moderate anxiety. Therefore, it is necessary to conduct a study on the effects of mindfulness on the anxiety in the elderly Hindus.

\section{OBJECTIVE}

This study aimed to determine the effects of mindfulness therapy with Gayatri mantra on decreasing anxiety in the elderly Hindus.

\section{METHODS}

The present study used a one group pre and posttest quasi-experimental design and was conducted in Wana Seraya social home in Bali, Indonesia from 29 April to 4 June 2017. This study was approved by the Ethics Committee of the Faculty of Medicine, Diponegoro University. The population was all the elderly living in the social home $(n=48)$. Thirty-four elderly Hindus who met the inclusion criteria were selected as the samples. The inclusion criteria were: (1) Hindus of aged 60-89 years old, 2) signing the informed consent, 3 ) having the anxiety of up to moderate level, 4) able to perform selfmobilization, and 5) did not take anti-anxiety medication. Purposive sampling was used to recruit the samples.

Geriatric Anxiety Scale (GAS) was used to measure the level of anxiety. This questionnaire consisted of 25 items covering three domains: somatic (9 questions), cognitive (8 questions) and affective domains (8 questions). A Likert scale was used in the questionnaire, ranging from 0 to 3 . The intervention given was mindfulness therapy with Gayatri mantra. The therapy was given in four stages: preparation stage, preinteraction stage, work stage, and evaluation stage. In this study, the elderly people were trained to practice mindfulness with Gayatri mantra. Results of the training were measured using the Cognitive and Affective Mindfulness Scale-Revised (CAMS-R). The elderly would pass the training if the CAMS-R score was $\geq 75$, and would fail if the score was $<75$. The results of CAMS-R measurement showed that 34 elderly passed the training with an average score of 78.06 .

The intervention in this study was given to the elderly for five weeks. A guided training session was conducted in two weeks for four sessions, whereas the supervised practice was carried out in one week for two practice sessions. Observations were conducted at the end of the third week to ensure that the elderly were able to practice mindfulness. Furthermore, the elderly were also given a two-week time to have independent practice with necessary supervision in four training sessions. Evaluations and posttests were administered in two days at the end of the fifth week.

To determine normality of the obtained GAS scores before and after the intervention, a Shapiro-Wilk test was performed. The result obtained a $p$-value of $>0.05$, indicating that the data were normally distributed so that to test the hypothesis, a paired t-test would be used.

\section{RESULTS}


HOLISTIK NURSING AND HEALTH SIENCE 1, (1), 2018 35-45

Table 1. Results of homogeneity test of the elderly anxiety based on the age $(n=34)$

\begin{tabular}{lcccccc}
\hline Variable & $\mathrm{n}$ & Mean & Median & Min-Max & $\begin{array}{l}\text { 95\% CI } \\
\text { (Upper-Lower) }\end{array}$ & $p$-value \\
\hline Age & 34 & 76.53 & 77.50 & $60-89$ & $73.65-79.41$ & 0.807 \\
\hline
\end{tabular}

Table 2. Results of homogeneity test based on the participant characteristics (age, sex, educational background, employment history, family) $(n=34)$

\begin{tabular}{|c|c|c|c|c|c|}
\hline No & Variables & Characteristics & $\mathrm{n}$ & $\%$ & $p$-value \\
\hline \multirow[t]{2}{*}{1} & Age & a. Elderly (60-74) & 14 & 41.2 & \multirow[b]{2}{*}{-} \\
\hline & & b. Old (75-89) & 20 & 58.8 & \\
\hline \multirow[t]{2}{*}{2} & Sex & a. Male & 9 & 26.5 & \multirow{2}{*}{0.255} \\
\hline & & b. Female & 25 & 73.5 & \\
\hline \multirow[t]{2}{*}{3} & Education background & a. Un-educated & 15 & 44.1 & \multirow{2}{*}{0.754} \\
\hline & & b. Educated & 19 & 55.9 & \\
\hline \multirow[t]{2}{*}{4} & Employment history & a. Unemployed & 8 & 23.5 & \multirow{2}{*}{0.120} \\
\hline & & b. Employed & 26 & 76.5 & \\
\hline \multirow[t]{2}{*}{5} & Family companion & a. Yes & 12 & 35.3 & \multirow{2}{*}{0.029} \\
\hline & & b. No & 22 & 64.7 & \\
\hline
\end{tabular}

Table 3. Levels of anxiety before and after the intervention $(n=34)$

\begin{tabular}{llrlrl}
\hline & \multicolumn{1}{c}{ Variables } & \multicolumn{2}{c}{ Before } & \multicolumn{2}{c}{ After } \\
& & $\mathrm{n}$ & $\%$ & $\mathrm{n}$ & $\%$ \\
\hline a. & Minimal & 8 & $23.53 \%$ & 34 & $100 \%$ \\
b. & Mild & 26 & $76.47 \%$ & 0 & 0 \\
c. & Moderate & 0 & 0 & 0 & 0 \\
d. & Severe & 0 & 0 & 0 & 0 \\
& Total & 34 & $100 \%$ & 34 & $100 \%$ \\
\hline
\end{tabular}

Table 3 shows that before the intervention, out of 34 elderly people, 26 (76.47\%) had mild anxiety and $8(23.53 \%)$ had minimal anxiety. After the intervention, all the elderly $(100 \%)$ had decreased anxiety to a minimal level. 
HOLISTIK NURSING AND HEALTH SIENCE 1, (1), 2018 35-45

Table 4. Levels of anxiety based on three domains of Geriatric Anxiety Scale (GAS) before and after the intervention $(n=34)$

\begin{tabular}{lrrrr}
\hline \multicolumn{1}{c}{ Variables } & Before & & After & \\
& $\mathrm{n}$ & $\%$ & $\mathrm{n}$ & $\%$ \\
\hline 1. Somatic & & & & \\
a. Minimal & 11 & 32.4 & 34 & 100 \\
b. Mild & 23 & 67.6 & 0 & 0 \\
c. Moderate & 0 & 0 & 0 & 0 \\
d. Severe & 0 & 0 & 0 & 0 \\
2. Cognitive & & & & 100 \\
a. Minimal & 15 & 44.1 & 34 & 0 \\
b. Mild & 18 & 52.9 & 0 & 0 \\
c. Moderate & 1 & 2.9 & 0 & 0 \\
d. Severe & 0 & 0 & 0 & 0 \\
3. Affective & & & & 0 \\
a. Minimal & 9 & 26.5 & 34 & 0 \\
b. Mild & 21 & 61.8 & 0 & 0 \\
c. Moderate & 4 & 11.8 & 0 & 0 \\
d. Severe & 0 & 0 & 0 & 0 \\
\hline
\end{tabular}

Table 4 shows that there were changes in the GAS scores on somatic, cognitive and affective domains. The level of anxiety in the somatic domain, cognitive domain, and affective domain showed the highest score of $67.6 \%$ (mild anxiety), $52.9 \%$ (mild anxiety), and $61.8 \%$ (mild anxiety), respectively. After the intervention, the somatic, cognitive and affective domains changed to minimal anxiety (100\%).

Table 5. Mean of anxiety level before and after the intervention $(n=34)$.

\begin{tabular}{|c|c|c|c|c|c|c|}
\hline Group & Variables & $\mathrm{n}$ & Mean \pm SD & Median & Min-Max & $\begin{array}{c}95 \% \text { CI } \\
\text { (Upper-Lower) }\end{array}$ \\
\hline \multirow{2}{*}{ Treatment } & Before & \multirow{2}{*}{34} & $25.5 \pm 8.6$ & 26.5 & $7-38$ & $28.50-22.5$ \\
\hline & After & & $7.8 \pm 3.2$ & 8.0 & $2-14$ & $8.96-6.7$ \\
\hline
\end{tabular}

Table 5 shows a decreased mean of anxiety before and after the intervention. The mean before the treatment was 25.5 with the highest score of 38 and the lowest score of 7 . Meanwhile, after the intervention, the mean decreased to 7.8 with the highest and lowest scores of 11 and 2, respectively.

Table 6. Effects of mindfulness with Gayatri mantra on the anxiety in the elderly $(n=34)$

\begin{tabular}{clcccc}
\hline Group & Variables & $\begin{array}{c}\text { Mean } \\
\text { difference }\end{array}$ & t & $\begin{array}{c}95 \% \text { CI } \\
\text { (Upper-Lower) }\end{array}$ & p-value \\
\hline \multirow{2}{*}{ Treatment } & $\begin{array}{l}\text { Before } \\
\text { After }\end{array}$ & 17.65 & 14.213 & $15-20$ & 0.000 \\
\hline
\end{tabular}

Table 6 indicates decreased anxiety as much as 17.65 with a p-value of 0.000 , and $\alpha$ of 0.05 . The $\mathrm{p}$-value was $<\alpha$, meaning that there was a difference in the mean score before and after the intervention. In other words, mindfulness with Gayatri mantra significantly decreased anxiety in the elderly Hindus. 
HOLISTIK NURSING AND HEALTH SIENCE 1, (1), 2018 35-45

\section{DISCUSSION}

\section{Level of anxiety in the elderly before and after given the intervention}

Based on the findings, it was indicated that before the intervention, most of the elderly $(n=26$ or $76.47 \%)$ had mild anxiety, and after the intervention, the anxiety reduced to a minimal level. This finding is relevant to a study by Irshad \& Chaudhry (2015), which revealed that anxiety was a major psychological disorder at present, and its effect on older adults was detrimental. In their study, $15 \%$ of the total respondents were suffered from higher anxiety than any other psychological disorders. The present study also supports a study by Yusuf, Fitryasari, Rizky \& Hanik (2015) which defined anxiety as a normal reaction due to the emergence of stimuli in the form of stressors or threats. Anxiety is an emotional reaction to a hazard (real or unreal), involving feelings, behaviors and physiological responses (Gask \& Graham, 2014).

In this study, the level of anxiety in the elderly decreased from 25.5 to 7.8 after given the intervention. This finding is consistent with Segal and Coolidge (2001) who argued that older adults usually used more adaptive treatment strategies than the young ones. Furthermore, most participants in this study were old elderly people (58.8\%). According to Tarwoto and Wartonah (2008), the level of maturity and the power of individuals in thinking skill could be identified as someone is getting older. Stuart (2005) argued that individual's perspective in solving problems is affected by the age.

The result of this study is also supported by Segal and Coolidge (2001) which stated that older adults usually used more adaptive treatment strategies than the young ones. Erikson (2010) asserted that ego maturity characterizes the individuals who are entering the age of 60 and more due to the previous experiences they have gained. As the individuals are getting older, they will achieve an emotional maturity, so that they will always try to reduce or overcome hopelessness or anxiety in accordance with the past experiences. Elderly people are in the final stage of aging and have gained a lot of experiences in their lives. These experiences make the elderly tend to be more receptive to their internal experiences without negative judgment or rejection of emotions, and unpleasant sensations.

\section{Effects of mindfulness with Gayatri mantra on anxiety in the elderly}

The result of paired t-test showed that the mean value of anxiety had a decrease of 17.65 with a $p$-value of 0.000 and $\alpha$ of 0.05 , where $p$ was $<\alpha$. The decreased score proves that mindfulness with Gayatri mantra had an effect on reducing anxiety in the elderly. This finding is consistent with a study by Sundquist, et al. (2015) which found that groupbased therapy of mindfulness was not inferior to the usual treatment for depressed patients, anxiety, stress, and difficulty for adaptation with a p-value of $0.001(\alpha<0.05)$.

The result of paired t-test analysis in the present study indicated a significant decrease in the level of anxiety before and after the intervention. This decrease occurred due to the intervention of mindfulness with Gayatri mantra which was routinely performed twice a week for five weeks with a duration of 30 minutes each. This intervention is a combination of mindfulness with Gayatri mantra (faith) played through songs. 
The way a human solves a problem depends on how often the brain gets a stimulus or exercise. More positive stimulation will lead the brain to learn to reflect the thoughts which judge someone. If the mindful condition can be achieved, the individuals will be able to control the emotions without having to hurt the human body and mind (KabatZinn, 1990; Davis \& Hayes, 2011; Hofmann \& Diana, 2010). A study by Koszycki, Thake, Mavounza, et al. (2016) proved that mindfulness-based intervention for social anxiety disorder was able and feasible to decrease the severity of social anxiety symptoms ( $\mathrm{p}<0.0001)$.

In Hinduism, individuals entering retirement age are known as being in the life stage of wanaprastha. In the wanaprastha, the elderly life begins to gradually keep a distance from worldly attributes and gives more priority to the family. The elderly will prefer to their personal focus on spirituality and approaches to God as well as prioritize spiritual happiness by lowering ego and emotion (Wikipedia, 2016). Mindfulness therapy with Gayatri mantra greatly assists the elderly in managing the sources of anxiety and make them more aware of their existence. They also have full confidence that life must keep running as it should be. Therefore, the elderly can be free from any psychological and physical sufferings.

The results of mindfulness skill measurement using CAMS-R indicated that all the elderly passed the training with a mean score of 78.06. Mindfulness is associated with a consciousness which can be developed by paying attention in certain ways: deliberately, in the present time, and nonjudgmental of events as they are. This allows the individuals to see what happens in their lives (Teasdale, Williams \& Segal, 2014).

Mindfulness combined with Gayatri mantra is a mind-based consciousness meditation which is based on the belief and prayer. Being conscious means able to see all aspects of life such as experience, sensations in the body, feelings, memories, smell, hearing, touch, and taste (Teasdale, Williams \& Segal, 2014). Awareness can help the elderly to reflect all forms of positive and negative experiences they have gone through to foster the belief in their current condition. With the confidence developed from the awareness, the elderly will be more sincere and more receptive to their current condition.

The finding in this study is consistent with a study by Parswani, Sharma, \& Iyengar (2013), which revealed that blood pressure, heart rate, respiration rate and oxygen consumption had positive responses to mindfulness. Similar physiological effects were also seen in the relaxation responses. Mindfulness activates the autonomic nervous system to release endorphins and serotonin, and a parasympathetic response that affects the endocrine responses and immune. Similarly, the chants of ' $O M$ ' and 'Gayatri' will stimulate the brain cells to achieve activation and better concentration (Balaji, 2017). Thus, it appears that a combination of mindfulness with Gayatri mantra (faith \& prayer) makes the elderly people be more opened, cautious, and alert individuals, and thus they will have more ability to adapt by not giving reactions to the source of stress.

\section{CONCLUSION}


This study proved that mindfulness with Gayatri mantra had a significant effect on decreasing anxiety among the elderly Hindus. Nurses and other caregivers can use the similar therapy to reduce stress. They can implement the therapy to the elderly Hindus living in the nursing home as prevention for decreasing anxiety. Further studies can examine the effects of mindfulness and Gayatri mantra on psychological issues such as stress and depression. Further investigation of other characteristics affecting anxiety in the elderly such as social support (caregiver), cultures, and the environment is also needed.

\section{ACKNOWLEDGEMENT}

The authors would like to thank the Department of Investment and One Stop Integrated Service (PTSP) of Bali Province, the Nation Unity, Politics, and Protection of the People of Denpasar, Tresna Werdha Social Home in Wana Seraya, Denpasar for permitting the researchers to conduct this study in their region.

\section{REFERENCES}

Antariksawan, I. W. (2015). Hindu Mantram. Retrieved from https://www.facebook.com/hindumantras/posts/964256700285278:0

Baba, B.S.S.S. (1996). The Power And The Potency Of The Gayatri Mantra. Sri Lanka: The Sri Sathya Sai Organisation Sri Lanka (Region XV).

Balaji, D. (2017). Stress Management for Mantra Techniques. 2: 8-10.

Bali, Maruti Suta Center. (2014). Ajaran Meditasi Sejati Brahma Astra [Brahma Astra's True Meditation Teaching]. http://marutisuta.com/meditasi.html.

Centers for Disease Control and Prevention. (2010). The State of Mental Health and Aging in America. 1-12.

Central Bureau of Statistics. (2015). Statistik Penduduk Lanjut Usia Hasil Survei Sosial Ekonomi Nasional [Statistics of Elderly. Results of Social and Economic National Survey]. Jakarta.

Davis, D. M., \& Hayes, J. A. (2011). Practice Review What Are the Benefits of Mindfulness? A Practice Review of Psychotherapy-Related Research. Psychotherapy; Vol. 48, N. Epub ahead of print. DOI: 10.1037/a0022062.

Directorate General of Learning and Student Affairs. (2016). Pendidikan Agama Hindu: Untuk Perguruan Tinggi. 1st ed. Direktorat Jenderal Pembelajaran dan Kemahasiswaan Kementerian Riset Teknologi dan Pendidikan Tinggi [Hindu Religious Education for Higher Education. 1st ed. Directorate General of Learning and Student Affairs of the Ministry of Research, Technology and Higher Education]. Retrieved from http://luk.staff.ugm.ac.id/atur/mkwu/4PendidikanAgamaHindu.pdf.

Erikson, E., H., (2010). Childhood and Society. 1st ed. Yogyakarta: Pustaka Pelajarpustakapelajar@talkom.net.318-320.

F., Didonna. (2008). Clinical Handbook of Mindfulness. New York: Springerwww.nicabm.com.

Gask, Linda \& Graham, C. C. (2014). ABC of Anxiety and Depression. 1st ed. Wiley Blackwell: BMJ Bookswww.abcbookseries.com.

Hawari, D. (2011). Manajemen Stres, Cemas dan Depresi. 2nd ed [Management of Stress, Anxiety and Depression]. Jakarta: Balai Penerbit FKUI. 
Hofmann, Stefan G., Sawyer, Alice T., Witt, Ashley A., \& Oh, Diana. (2010). The Effect of Mindfulness-Based Therapy on Anxiety and Depression: A MetaAnalytic Review. J Consult Clin Psychol; Vol. 78, N. Epub ahead of print. DOI: $10.1037 / \mathrm{a} 0018555$.

Irshad, M. K., \& Chaudhry, A. G. (2015) Psychological Disorders; Old, Age, and Prevalence. 22: 1-4.

Kabat-Zinn, Jon. (1990). Full Catastrophe Living: Using the Wisdom of Your Body and Mind to Face Stress, Pain, and Illness. New York: Delta Trade Paperbacks.

Keshavadas, S. S. Translated by Agus S. Mantik. (2007). Gayatri, Semedhi Mahatinggi [Gayatri, The Highest Semedhi]. 4th ed. Denpasar Bali: PT Pustaka Manikgeniraditya-majalah@yahoo.com.

Koszycki, D., Thake, J., et al. (2016). Preliminary Investigation of a Mindfulness-Based Intervention for Social Anxiety Disorder That Integrates Compassion Meditation and Mindful Exposure. J Altern Complement Med, 22: 363-374.

Mahoney, T. Colin, Segal, L. Daniel, \& Coolidge, L. Frederick. (2015). Anxiety Sensitivity, Experiential Avoidance, and Mindfulness Among Younger and Older Adults: Age Differences in Risk Factors for Anxiety Symptoms. Int J Aging Hum Dev. 81: 217-40.

Ministry of Health of Republic of Indonesia (MHRI). (2014). Infodatin Pusat Data dan Informasi: Situasi dan Analisis Lanjut Usia [Data Resource and Information: A Situation and Analysis of the Elderly]. Jakarta.

Mujahidullah, Khalid. (2012). Keperawatan Geriatrik Merawat Lansia dengan Cinta dan Kasih Sayang [Geriatric Nursing: Caring for the Elderly with Love and Affection]. Yogyakarta: Pustaka Pelajar.

Nursalam. (2015). Metodologi Penelitian Ilmu Keperawatan: Pendekatan Praktis. 4th ed [Research Method in Nursing: A Practical Approach]. Jakarta: Salemba Medika.

Parswani, Manish J., Sharma, Mahendra P., \& Iyengar, SS. (2013). Mindfulness-based stress reduction program in coronary heart disease: A randomized control trial. International journal of yoga, 6: 111-7.

Safaria, T \& Saputra, EN. (2012). Manajemen Emosi Sebuah Panduan Cerdas Bagaimana Mengelola Emosi Positif Dalam Hidup Anda. Edisi I [Management of Emotion: Smart Guidelines on Managing Your Positive Emotions]. Jakarta: PT. Bumi Aksarainfo@bumiaksara.co.id.

Segal, Daniel L., Hook, Julie, N., \& Coolidge, F. L. (2001). Personality Dysfunction, Coping Styles, and Clinical Symptoms in Younger and Older Adults.7: 201202.

Stuart W.Gail. (2005). Principles and Practice of Psychiatric Nursing. 9th edition. St. Louis, Missouri: MOSBY Elsevier.

Subandi, Lestari R. \& Suprianto, T. (2013). Pengaruh Terapi Psikoreligius Terhadap Penurunan Tingkat Ansietas Pada Lansia di UPT Pelayanan Sosial Lanjut Usia Sejahtera Pandaan Pasuruan [The Effects of Psycho-religious Therapy on Reducing Anxiety Level in the Elderly Social Service in Pasuruan]. (pp.1-2).

Sundquist, Jan., et al. (2015). Mindfulness group therapy in primary care patients with depression, anxiety and stress and adjustment disorders: Randomised controlled trial. Br J Psychiatry, 206: 128-135. 
Tarwoto dan Wartonah. (2008). Kebutuhan Dasar Manusia dan Proses Keperawatan [Human Basic Needs in Nursing Process]. Pertama. Jakarta: Salemba Medika.

Teasdale, Jhon., Williams, Mark., \& Segal Z. (2014). The Mindful Way Work Book An 8-Week Program to Free Yourself from Depression and Emotional Distress. New York: The Guilford Presswww.guilford.com.

Thomas, S. \& Rao, L. S. (2016). Effect of Gayatri Mantra Meditation on Meditation Naive Subjects : an EEG and fMRI Pilot Study. 3; 15-18.

Tomaselli, K. A. (2014). The Effect Of Mindfulness-Based Music Listening on The Anxiety Symptoms and Awareness of Older Adults in a Senior Living FacilityMicroform Edition (C) ProQuest LLC.

Wikipedia. (2016). Catur Ashrama [The Four Ashrama]. https://id.wikipedia.org/wiki/Caturasrama, accessed 1 January 2016.

Wolitzky-Taylor, Kate B., Castriotta, Natalie., Lenze, Eric J., Stanley, Melinda A., \& Craske, Michelle G., (2010). Anxiety Disorder In Older Adults: A Comprehensive Review.; 191-194.

Yusuf, A., Fitryasari, P. K, Rizky, Nihayati, \& Hanik, E. (2015). Buku Ajar Keperawatan Kesehatan Jiwa [Module of Mental Health Nursing]. Jakarta: Salemba Medikahttp://www.penerbitsalemba.com. 